\title{
ANALISIS BEBAN KERJA MENTAL PADA OPERATOR AIR TRAFFIC CONTROLLER (ATC) DENGAN METODE SUBJEKTIF DAN OBJEKTIF (STudi kasus : airnav bandar udara XYZ)
}

\author{
Lina Dianati Fathimahhayati, Willy Tambunan, Rizka Amanda Putri \\ Program Studi Teknik Industri \\ Universitas Mulawarman \\ Jalan Sambaliung No. 9, Kampus Gunung Kelua, Samarinda \\ Email : linadianatif@gmail.com
}

\begin{abstract}
An Air Traffic Controller (ATC) operator is required to always concentrate on monitoring navigation, radiation as well as supervising and implementing aircraft guidance. Obviously such work can lead to a mental workload on the worker. Based on these problems, it is necessary to do a research on the analysis of mental workload on the operator ATC at $X Y Z$ Airport. Measurement of mental workload can be done in two ways: subjective measurement and objective measurement. Subjective measurements of the mental workload can be done with NASA-TLX method. While the objective measurement can be done by doing the measurement physiologically such as through the heart rate. The results showed that the metal workload of ATY operator of XYZ Airport was in high category and very high base on subjective measurement. Performance level is the dominant factor causing high mental work load perceived by ATC operator. While based on the objective measurement found that the mental workload of ATC operators are in the medium category.
\end{abstract}

Keywords : ATC Operators, NASA-TLX, Heart Rate

Abstrak

Seorang operator Air Traffic Controller (ATC) dituntut untuk selalu berkosentrasi tinggi dalam memantau navigasi, radiasi serta mengawasi dan melaksanakan pemanduan pesawat sehingga dapat menjamin keamanan serta keteraturan traffic dalam penerbangan jarak jauh maupun penerbangan jarak dekat. Tentunya pekerjaan tersebut dapat menimbulkan beban kerja mental pada pekerjanya. Berdasarkan permasalahan tersebut, maka perlu dilakukan penelitian mengenai analisis beban kerja mental pada operator ATC Bandar Udara $\mathrm{XYZ}$. Pengukuran beban kerja mental dapat dilakukan dengan dua cara yaitu pengukuran secara subyektif dan pengukuran secara obyektif. Pengukuran beban kerja mental secara subyektif dapat dilakukan dengan metode NASA-TLX. Sedangkan pengukuran secara obyektif dapat dilakukan dengan melakuan pegukuran secara fisiologis diantaranya melalui denyut jantung. Hasil penelitian menunjukkan bahwa beban kerja metal operator ATC Bandar Udara XYZ berada pada kategori tinggi dan sangat tinggi jika dilihat dari pengukuran secara subjektif. Tingkat Performansi merupakan faktor dominan yang menyebabkan tingginya beban kerja mental yang dirasakan oleh operator ATC tersebut. Sedangkan berdasarkan pengukuran objektif didapatkan bahwa beban kerja operator ATC berada pada kategori sedang.

Kata Kuci : Operator ATC, NASA-TLX, Denyut Jantung 


\section{Latar Belakang Masalah}

Operator Air Traffic Controller (ATC) bekerja untuk mengatur pelayanan navigasi dan radar serta menjalin komunikasi yang baik dengan pilot maupun co-pilot sehingga tidak terjadi suatu kesalahan yang fatal menimpa pada penerbangan tersebut. Beban kerja yang dialami oleh operator ATC merupakan beban kerja mental dikarenakan dalam melaksanakan pekerjaannya operator dituntut untuk berkosentrasi tinggi dalam memantau navigasi, radiasi serta mengawasi dan melaksanakan pemanduan pesawat sehingga dapat menjamin keamanan serta keteraturan traffic dalam penerbangan jarak jauh maupun penerbangan jarak dekat.

AirNav XYZ merupakan perusahaan yang bergerak dalam industri penerbangan bertugas memberikan pelayanan navigasi dan mengatur pergerakan lalu lintas pesawat di Bandar Udara XYZ, Balikpapan. Pelayanan navigasi membutuhkan ketelitian dari seorang controller untuk melakukan proses scanning pada air situation display dalam mengatur traffic pesawat yang akan take off dan landing di Bandar Udara XYZ dan melayani pesawat overflying di bawah FL245 di area Balikpapan TMA serta semua penerbangan dari dan yang akan menuju Bandar Udara Temindung, Samarinda. Wilayah pengawasan yang sangat luas membuat beban kerja yang dirasa controller sangatlah tinggi dikarenakan pada kondisi kerja tertentu terdapat traffic yang sangat padat yaitu dapat mencapai lebih dari 20 traffic per jamnya. Menurut Pheasant (1991) dalam Simanjuntak (2010) beban kerja mental adalah pekerjaan dengan kemampuan pekerja untuk memenuhi tuntutan pekerjaan dengan menggunakan mental yang tinggi (otak sebagai pencetus utama).

Berdasarkan permasalahan tersebut, maka perlu dilakukan penelitian mengenai analisis beban kerja mental pada operator ATC Bandar Udara XYZ. Pengukuran beban kerja mental dapat dilakukan dengan dua cara yaitu pengukuran secara subyektif dan pengukuran secara obyektif. Pengukuran beban kerja mental secara subyektif dapat dilakukan dengan metode NASA-TLX. Metode NASA-TLX merupakan metode dengan pengukuran subyektif beban kerja mental berdasarkan persepsi respoden dengan berdasarkan enam faktor yaitu kebutuhan mental, kebutuhan fisik, kebutuhan waktu, performansi, tingkat frustasi, dan tingkat usaha. Sedangkan pengukuran secara obyektif dapat dilakukan dengan melakukan pengukuran secara fisiologis diantaranya melalui denyut jantung.

\section{Metodologi Penelitian}

Subyek penelitian ini adalah operator ATC pada Airnav Bandar Udara XYZ. Penelitian ini menggunakan teknik purposive sampling dengan subyek yang diteliti hanya berjenis kelamin laki-laki dengan jumlah sembilan orang. Pengukuran beban kerja mental dilakukan secara subjektif dengan menggunakan kuisioner NASA-TLX dan secara objektif dengan menggunakan pengukuran denyut jantung.

Metode NASA-TLX dikembangkan oleh Sandra G. Hart dari NASA-Ames Research Center dan Lowell E. Staveland dari San Jose State University pada tahun 1981. Metode ini berupa kuesioner yang dikembangkan berdasarkan munculnya kebutuhan pengukuran subyektif yang lebih mudah namun lebih sensitif pada pengukuran beban kerja. NASA-TLX memiliki enam indikator beban mental yang dapat diukur seperti ditunjukkan pada Tabel 1.

Tabel 1. Indikator Beban Mental NASA-TLX

\begin{tabular}{|c|l|}
\hline SKALA & \multicolumn{1}{c|}{ KETERANGAN } \\
\hline $\begin{array}{c}\text { Kebutuhan Mental } \\
(\mathrm{KM})\end{array}$ & $\begin{array}{l}\text { Seberapa besar aktivitas mental dan perseptual yang } \\
\text { dibutuhkan untuk melihat, mengingat dan mencari. Apakah } \\
\text { pekerjaan tersebut mudah atau sulit, sederhana atau } \\
\text { kompleks, longgar atau ketat. }\end{array}$ \\
\hline $\begin{array}{c}\text { Kebutuhan Fisik } \\
(\mathrm{KF})\end{array}$ & $\begin{array}{l}\text { Jumlah aktivitas fisik yang dibutuhkan (missal: mendorong, } \\
\text { menarik, mengontrol putaran, dll) }\end{array}$ \\
\hline
\end{tabular}




\begin{tabular}{|c|l|}
\hline $\begin{array}{c}\text { Kebutuhan Waktu } \\
(\mathrm{KW})\end{array}$ & $\begin{array}{l}\text { Jumlah tekanan yang berkaitan dengan waktu yang } \\
\text { dirasakan selama elemen pekerjaan berlangsung. Apakah } \\
\text { pekerjaan perlahan atau santai atau cepat dan melelahkan }\end{array}$ \\
\hline $\begin{array}{c}\text { Performansi } \\
(\mathrm{P})\end{array}$ & $\begin{array}{l}\text { Seberapa besar keberhasilan seseorang di dalam } \\
\text { pekerjaannya dan seberapa puas dengan hasil kerjanya }\end{array}$ \\
\hline $\begin{array}{c}\text { Tingkat Frustasi } \\
(\mathrm{TF})\end{array}$ & $\begin{array}{l}\text { Seberapa tidak aman, putus asa, tersinggung, terganggu, } \\
\text { dibandingkan dengan perasaan aman, puas, nyaman, dan } \\
\text { kepuasan diri yang dirasakan. }\end{array}$ \\
\hline Tingkat Usaha (TU) & $\begin{array}{l}\text { Seberapa keras kerja mental dan fisik yang dibutuhkan } \\
\text { untuk menyelesaikan pekerjaan }\end{array}$ \\
\hline
\end{tabular}

Hancock dan Meshkati (1989) menjelaskan langkah-langkah dalam pengukuran beban kerja mental dengan menggunakan metode NASA-TLX sebagai berikut :

\section{a. Pembobotan}

Bagian ini responden diminta untuk memberikan tanda silang salah satu dari dua indikator yang dirasakan lebih dominan menimbulkan beban kerja mental terhadap pekerjaan tertentu. Kuesioner NASA-TLX yang diberikan berbentuk perbandingan berpasangan yang terdiri dari 15 perbandingan berpasangan. Dari kuesioner ini dihitung jumlah tally dari setiap indikator yang dirasakan paling berpengaruh. Jumlah tally ini kemudian akan menjadi bobot untuk setiap indikator beban mental. Perbandingan berpasangan sebanyak 15 indikator dalam kuesioner NASA-TLX yang akan digunakan dalam penelitian ini dapat dilihat pada Tabel 2.

Tabel 2. Perbandingan Berpasangan NASA-TLX

\begin{tabular}{|c|c|c|c|c|}
\hline \multirow{2}{*}{ No } & \multirow{2}{*}{ X } & \multicolumn{2}{|c|}{$\begin{array}{c}\text { PERBANDINGAN BERPASANGAN INDIKATOR } \\
\text { BEBAN KERJA MENTAL }\end{array}$} & X \\
\hline 1 & & Tingkat Usaha (TU) & Performance (P) & \\
\hline 2 & & Kebutuhan Waktu (KW) & Tingkat Frustasi (TF) & \\
\hline 3 & & Kebutuhan Waktu (KW) & Tingkat Usaha (TU) & \\
\hline 4 & & Kebutuhan Fisik (KF) & Tingkat Frustasi (TF) & \\
\hline 5 & & Performance (P) & Tingkat Frustasi (TF) & \\
\hline 6 & & Kebutuhan Fisik (KF) & Kebutuhan Waktu (KW) & \\
\hline 7 & & Kebutuhan Fisik (KF) & Performance (P) & \\
\hline 8 & & Kebutuhan Waktu (KW) & Kebutuhan Mental (KM) & \\
\hline 9 & & Tingkat Frustasi (TF) & Tingkat Usaha (TU) & \\
\hline 10 & & Performance (P) & Kebutuhan Mental (KM) & \\
\hline 11 & & Performance (P) & Kebutuhan Waktu (KW) & \\
\hline 12 & & Kebutuhan Mental (KM) & Tingkat Usaha (TU) & \\
\hline 13 & & Kebutuhan Mental (KM) & Kebutuhan Fisik (KF) & \\
\hline 14 & & Tingkat Usaha (TU) & Kebutuhan Fisik (KF) & \\
\hline 15 & & Tingkat Frustasi (TF) & Kebutuhan Mental (KM) & \\
\hline
\end{tabular}

\section{b. Pemberian Rating}

Bagian ini responden diminta memberi rating terhadap keenam indikator beban mental. Rating yang diberikan adalah subyektif tergantung pada beban mental yang dirasakan oleh responden tersebut. Pemberian rating terhadap enam indikator yang akan digunakan dalam penelitian ini dapat dilihat pada Tabel 3. 
Tabel 3. Rating Indikator NASA-TLX

\begin{tabular}{|c|c|c|}
\hline PERTANYAAN & SKALA & \\
\hline \multirow{3}{*}{$\begin{array}{l}\text { 1. Kebutuhan Mental (KM) } \\
\text { Usaha mental yang anda butuhkan } \\
\text { untuk menvelesaikan tugas anda? }\end{array}$} & Rendah & \multirow{3}{*}{$\begin{array}{r}\text { Tinggi } \\
100\end{array}$} \\
\hline & 0 & \\
\hline & Nilai anda: & \\
\hline \multirow[t]{3}{*}{ 2. Kebutuhan Fisik (KF) } & Rendah & \multirow{3}{*}{$\begin{array}{r}\text { Tinggi } \\
100\end{array}$} \\
\hline & 0 & \\
\hline & Nilai anda: & \\
\hline \multirow{3}{*}{$\begin{array}{l}\text { 3. Kebutuhan Waktu (KW) } \\
\text { Tekanan yang anda rasakan terkait } \\
\text { waktu untuk melakukan tugas anda? }\end{array}$} & Rendah & \multirow{3}{*}{$\begin{array}{r}\text { Tinggi } \\
100\end{array}$} \\
\hline & & \\
\hline & Nilai anda: . & \\
\hline \multirow{3}{*}{$\begin{array}{l}\text { 4. Performansi (P) } \\
\text { Tingkat keberhasilan anda dalam } \\
\text { melakukan tugas anda? }\end{array}$} & Rendah & \multirow{3}{*}{$\begin{array}{r}\text { Tinggi } \\
100\end{array}$} \\
\hline & & \\
\hline & Nilai an & \\
\hline \multirow{3}{*}{$\begin{array}{l}\text { 5. Tingkat Frustasi (TF) } \\
\text { Kecemasan, perasaan tertekan, dan } \\
\text { stres yang anda rasakan dalam } \\
\text { melakukan tugas anda? }\end{array}$} & Rendah & \multirow{3}{*}{$\begin{array}{r}\text { Tinggi } \\
100\end{array}$} \\
\hline & $0 \quad-----$ & \\
\hline & Nilai anc & \\
\hline \multirow{3}{*}{$\begin{array}{l}\text { 6. Tingkat Usaha (TU) } \\
\text { Kerja fisik dan mental yang anda } \\
\text { butuhkan dalam menyelesaikan tugas } \\
\text { anda? }\end{array}$} & Rendah & \multirow{3}{*}{$\begin{array}{r}\text { Tinggi } \\
100\end{array}$} \\
\hline & & \\
\hline & Nilai anda: . & \\
\hline
\end{tabular}

Hancock dan Meshkati (1988) menjelaskan data dari tahap pemberian rating diperlukan untuk memperoleh beban kerja (mean weighted workload) sebagai berikut :

a) Menghitung Produk

Produk diperoleh dengan cara mengalikan rating dengan faktor untuk masing-masing deskriptor. Dengan demikian dihasilkan enam nilai produk untuk enam indikator (KM,KW,KF,P,TU, dan TF). Menghitung produk dapat dicari dengan menggunakan Persamaan 1.

Produk = Rating * Bobot kerja.

b) Menghitung Weighted Workload (WWL)

WWL diperoleh dengan cara menjumlahkan keenam nilai produk. WWL dapat dicari dengan menggunakan Persamaan 2.

$W W L=\sum$ produk

c) Menghitung Rata-rata WWL

Rata-rata WWL diperoleh dengan cara membagi WWL dengan bobot total. Rata-rata WWL dapat dicari dengan menggunakan Persamaan 3.

$$
\text { Skor }=\frac{\text { EProduk }}{15}
$$

d) Interpretasi Nilai Skor

Hart dan Staveland (1988) menjelaskan dalam teori NASA-TLX, skor beban kerja yang diperoleh dapat diintepretasikan sebagai berikut : 
1. Nilai skor $>80$ menyatakan beban pekerjaan berat,

2. Nilai skor 50-70 menyatakan beban pekerjaan sedang, dan

3. Nilai skor $<50$ menyatakan beban pekerjaan ringan.

Menurut Simanjuntak (2010), kategori beban kerja mental diklasifikasikan menjadi lima indikator sebagai berikut :

1. Nilai skor 0-9 menyatakan beban kerja rendah,

2. Nilai skor 10-29 menyatakan beban kerja sedang,

3. Nilai skor 30-49 menyatakan beban kerja agak tinggi,

4. Nilai skor 50-79 menyatakan beban kerja tinggi, dan

5. Nilai skor 80-100 menyatakan beban kerja tinggi sekali.

Sedangkan, salah satu pilihan metode untuk pengambilan data yang paling banyak digunakan untuk mengetahui beban kerja mental secara objektif adalah denyut jantung (Karhiwikarta, 1996 dalam Putri, 2009). Pelaksanaan cara ini sangat mudah karena denyut jantung relatif mudah diukur dan pengukuran lebih efektif. Pengukuran denyut jantung dilakukan terhadap responden yang diteliti menggunakan alat pulse oximeter fox-2 (elitech technivision). Klasifikasi beban kerja menggunakan data denyut jantung dapat dilihat pada Tabel 4 (Tarwaka, 2015)

Tabel 4. Klasifikasi Beban Kerja berdasarkan Denyut Jantung

\begin{tabular}{|l|c|}
\hline \multicolumn{1}{|c|}{ Klasifikasi Pekerjaan } & Denyut Jantung/Menit \\
\hline Ringan & $75-100$ \\
\hline Sedang & $100-125$ \\
\hline Berat & $125-150$ \\
\hline Sangat Berat & $150-175$ \\
\hline Sangat Berat Sekali & $>175$ \\
\hline
\end{tabular}

\section{Hasil dan Pembahasan}

Hasil pengukuran beban kerja mental pada sembilan operator ATC Bandar Udara XYZ melalui pengukuran subjektif dengan metode NASA-TLX dapat dilihat pada Tabel 5.

Tabel 5. Beban Kerja Mental Operator ATC berdasarkan Pengukuran Subjektif

\begin{tabular}{|c|c|c|}
\hline Operator & $\begin{array}{c}\text { Skor NASA- } \\
\text { TLX }\end{array}$ & $\begin{array}{c}\text { Kategori } \\
\text { Beban Kerja }\end{array}$ \\
\hline Operator 1 & 81 & Tinggi Sekali \\
\hline Operator 2 & 78 & Tinggi \\
\hline Operator 3 & 80 & Tinggi Sekali \\
\hline Operator 4 & 78,3 & Tinggi \\
\hline Operator 5 & 77 & Tinggi \\
\hline Operator 6 & 78,3 & Tinggi \\
\hline Operator 7 & 78,7 & Tinggi \\
\hline Operator 8 & 80,3 & Tinggi Sekali \\
\hline Operator 9 & 78,3 & Tinggi \\
\hline Rata-rata & $\mathbf{7 8 , 9}$ & Tinggi \\
\hline
\end{tabular}

Adapun penilaian detail untuk setiap indikator beban kerja mental dapat dilihat pada Tabel 6 
Tabel 6. Nilai Indikator Beban Kerja Mental NASA-TLX

\begin{tabular}{|c|c|c|c|c|c|c|}
\hline \multirow{2}{*}{ Operator } & \multicolumn{7}{|c|}{ Indikator } \\
\cline { 2 - 7 } & $\mathbf{K M}$ & $\mathbf{K W}$ & $\mathbf{K F}$ & $\mathbf{P}$ & $\mathbf{T F}$ & $\mathbf{T U}$ \\
\hline Operator 1 & 367 & 117 & 27 & 482 & 0 & 225 \\
\hline Operator 2 & 403 & 73 & 23 & 443 & 0 & 230 \\
\hline Operator 3 & 475 & 128 & 17 & 367 & 0 & 213 \\
\hline Operator 4 & 360 & 143 & 20 & 450 & 0 & 203 \\
\hline Operator 5 & 475 & 137 & 17 & 360 & 0 & 167 \\
\hline Operator 6 & 367 & 162 & 25 & 467 & 0 & 153 \\
\hline Operator 7 & 267 & 120 & 37 & 422 & 0 & 337 \\
\hline Operator 8 & 398 & 113 & 27 & 420 & 17 & 230 \\
\hline Operator 9 & 347 & 120 & 27 & 472 & 0 & 147 \\
\hline Rata-rata & $\mathbf{3 8 4}$ & $\mathbf{1 2 4}$ & $\mathbf{2 4}$ & $\mathbf{4 3 1}$ & $\mathbf{2}$ & $\mathbf{2 1 2}$ \\
\hline
\end{tabular}

Berdasarkan hasil pengukuran dengan menggunakan metode subjektif terlihat bahwa beban kerja mental yang dirasakan oleh operator ATC Bandar Udara XYZ berada pada kategori tinggi sekali dan tinggi. Beban kerja yang dirasa oleh operator ATC tersebut memang sangat wajar dikarenakan dalam keseluruhan pekerjaannya membutuhkan kosentrasi tinggi untuk memantau dan mengawasi traffic yang dari dan menuju Bandar Udara XYZ maupun Bandar udara Temindung ataupun hany a melintas di wilay ah BPP TMA yang sangat luas. Menurut Budiman, dkk (2015) beban kerja yang dialami oleh seorang controller ATC terletak dari peak hours (jam sibuk). Operator ATC juga dituntut untuk berkonsentrasi tinggi dan ketepatan waktu dalam memantau serta mengatur departure dan arrival sehingga menjadikan traffic di Bandar Udara XYZ menjadi teratur.

Jika dilihat dari nilai setiap indikator pembentuk beban kerja mental, terlihat bahwa faktor Performansi (P) dan Kebutuhan Mental (KM) memiliki nilai yang paling tinggi dibandingkan indikator y ang lainnya. Performansi (P) sendiri menurut Hancock dan Meshkati (1988) yaitu seberapa besar keberhasilan seseorang di dalam pekerjaannya dan seberapa puas dengan hasil kerjaanya, sedangkan Kebutuhan Mental (KM) menurut Hancock dan Meshkati (1988) yaitu seberapa besar aktivitas mental dan perseptual yang dibutuhkan untuk melihat, mengingat dan mencari. Diketahui bersama bahwa dalam mengemban tugas sebagai operator ATC dibutuhkan kosentrasi yang tinggi dalam memantau, mengawasi, serta mengatur departure dan arrival dengan memberikan take off dan landing clearance. Jadi dapat disimpulkan kebutuhan mental serta performansi sangat mempengaruhi kinerja dari seorang operator ATC karena jika terjadi suatu kesalahan sedikitpun maka dapat dikatakan kinerja yang diberikan oleh operator ATC tidak dalam performa yang baik dan dapat menyebabkan resiko yang besar dalam dunia penerbangan.

Sedangkan pengukuran beban kerja mental pada sembilan operator ATC Bandar Udara XYZ melalui pengukuran objektif dengan denyut jantung dapat dilihat pada Tabel 7.

Tabel 7. Beban Kerja Mental Operator ATC berdasarkan Pengukuran Objektif

\begin{tabular}{|c|c|c|}
\hline Operator & $\begin{array}{c}\text { Denyut Jantung } \\
\text { (detak per menit) }\end{array}$ & $\begin{array}{c}\text { Kategori } \\
\text { Beban Kerja }\end{array}$ \\
\hline Operator 1 & 110,7 & Sedang \\
\hline Operator 2 & 106 & Sedang \\
\hline Operator 3 & 116,7 & Sedang \\
\hline Operator 4 & 106,3 & Sedang \\
\hline Operator 5 & 120 & Sedang \\
\hline Operator 6 & 113,3 & Sedang \\
\hline
\end{tabular}




\begin{tabular}{|c|c|c|} 
Operator 7 & 119 & Sedang \\
\hline Operator 8 & 126,7 & Berat \\
\hline Operator 9 & 124,7 & Sedang \\
\hline Rata-rata & $\mathbf{1 1 5 , 9}$ & Sedang \\
\hline
\end{tabular}

Perolehan beban kerja mental ke dalam kategori sedang pada pengukuran denyut jantung memang sangat wajar dikarenakan dalam melaksanakan pekerjaanya operator tidak terlalu dituntut menggunakan Kebutuhan Fisik (KF) berlebihan. Kebutuhan Fisik (KF) sendiri menurut Hancock dan Meshkati (1988) adalah jumlah aktivitas fisik yang dibutuhkan (mendorong, menarik, mengontrol putaran, dll) karena kondisi kerja dari operator sendiri hanya mengawasi air situation display dengan keadaan duduk. Selain itu operator juga diwajibkan dalam keadaan tenang ketika sedang melakukan pengawasan terhadap traffic yang ditangani serta AirNav sendiri mempunyai prosedur pada sistem kerja dimana sebelum bekerja operator ATC maupun semua pekerjanya diwajibkan untuk tes tekanan darah, jika tekanan darah dari controller ATC tinggi maka operator tersebut dilarang untuk melakukan pengawasan pada traffic. Dapat disimpulkan jika operator dalam keadaan tertekan maupun stress ketika sedang melakukan pengawasan maka traffic yang ditangani akan menjadi kacau dan dapat menyebabkan terancamnya keselamatan akan ratusan penumpang yang dari dan akan menuju Bandar Udara XYZ dan Bandar udara Temindung ataupun hanya melintas pada wilayah BPP TMA.

\section{Kesimpulan}

Berdasarkan hasil pengukuran beban kerja mental secara subjektif dengan menggunakan metode NASA-TLX didapatkan bahwa beban kerja mental operator ATC Bandar Udara XYZ berada pada kategori tinggi dan sangat tinggi. Sedangkan, rata-ratanya memiliki nilai 78,9 atau berada pada kategori tinggi. Tingkat Performansi merupakan faktor dominan yang menyebabkan tingginya beban kerja mental yang dirasakan oleh operator ATC tersebut. Namun, jika dilihat dari pengukuran objektif berupa pengukuran fisiologis yang dilihat dari denyut jantung operator, didapatkan bahwa kategori beban kerja yang dialami oleh operator ATC Bandar Udara XYZ berada pada kategori sedang, atau memiliki nilai 115, 9 detak per menit.

\section{Daftar Pustaka}

Budiman, J., Pujangkoro, Sugih A., dan Anizar, 2015, Analisis Beban Kerja Operator Air Traffic Control bandara XYZ dengan Menggunakan Metode NASA-TLX, Jurnal Teknik Industri FT USU Vol. 3 No. 3, Departemen Teknik Industri Fakultas Teknik USU, Medan.

Hancock, P.A., dan Meshkati, N., 1988, Human Mental Workload, University Of South California, CA.

Hart, S. G., dan Staveland, L. E., 1988, Development of Nasa-Task Load Index (Nasa-Tlx); Result of Empirical and Theoritical Research, Nasa-Ames Research Center. Moffet Field, CA.

Putri, M.R., 2009, Analisis Beban Kerja Mental pada Operator Cetak dengan Menggunakan Metode SWAT (Subjective Workload Assessment technique), ISSN: 2189- 1978, Fakultas Teknologi Industri UAJY, Yogjakarta.

Simanjuntak, R.A., 2010, Analisa Beban Kerja Mental dengan Metode NASA-Task Load Index, Jurnal Teknologi Technoscientia Vol. 3 No.1 ISBN: 1979-8415, Yogyakarta.

Tarwaka, 2011, Ergonomi Industri, Dasar-dasar Pengetahuan Ergonomi dan Aplikasi di Tempat Kerja, Cetakan kedua, UNIPRESS, Surakarta. 
